\title{
Article \\ OsARF11 Promotes Growth, Meristem, Seed, and Vein Formation during Rice Plant Development
}

\author{
Katherine Sims ${ }^{1}$, Fatemeh Abedi-Samakush ${ }^{1}$, Nicole Szulc ${ }^{1}$, Monika Gyongyi Macias Honti ${ }^{1,2}$ \\ and Jim Mattsson $1, *$ (D) \\ 1 Department of Biological Sciences, Simon Fraser University, 8888 University Drive, \\ Burnaby, BC V5A 1S6, Canada; Katherine_Sims@sfu.ca (K.S.); sama6365@gmail.com (F.A.-S.); \\ nszulc@alumni.ubc.ca (N.S.); monikagyongyi.maciashonti@kaust.edu.sa (M.G.M.H.) \\ 2 Plant Cell and Developmental Biology, King Abdullah University of Science and Technology, \\ Ibn Al Haytham Bldg.2, Thuwal 23955-6900, Saudi Arabia \\ * Correspondence: jim_mattsson@sfu.ca; Tel.: +1-778-782-4594
}

Citation: Sims, K.; Abedi-Samakush, F.; Szulc, N.; Macias Honti, M.G.; Mattsson, J. OsARF11 Promotes Growth, Meristem, Seed, and Vein Formation during Rice Plant Development. Int. J. Mol. Sci. 2021, 22, 4089. https://doi.org/10.3390/ ijms22084089

Academic Editor: Stephan Pollmann

Received: 9 March 2021

Accepted: 13 April 2021

Published: 15 April 2021

Publisher's Note: MDPI stays neutral with regard to jurisdictional claims in published maps and institutional affiliations.

Copyright: (c) 2021 by the authors. Licensee MDPI, Basel, Switzerland This article is an open access article distributed under the terms and conditions of the Creative Commons Attribution (CC BY) license (https:// creativecommons.org/licenses/by/ $4.0 /)$.

\begin{abstract}
The plant hormone auxin acts as a mediator providing positional instructions in a range of developmental processes. Studies in Arabidopsis thaliana L. show that auxin acts in large part via activation of Auxin Response Factors (ARFs) that in turn regulate the expression of downstream genes. The rice (Oryza sativa L.) gene OsARF11 is of interest because of its expression in developing rice organs and its high sequence similarity with MONOPTEROS/ARF5, a gene with prominent roles in $A$. thaliana development. We have assessed the phenotype of homozygous insertion mutants in the OsARF11 gene and found that in relation to wildtype, osarf11 seedlings produced fewer and shorter roots as well as shorter and less wide leaves. Leaves developed fewer veins and larger areoles. Mature osarf11 plants had a reduced root system, fewer branches per panicle, fewer grains per panicle and fewer filled seeds. Mutants had a reduced sensitivity to auxin-mediated callus formation and inhibition of root elongation, and phenylboronic acid (PBA)-mediated inhibition of vein formation. Taken together, our results implicate OsARF11 in auxin-mediated growth of multiple organs and leaf veins. OsARF11 also appears to play a central role in the formation of lateral root, panicle branch, and grain meristems.
\end{abstract}

Keywords: auxin response factor; auxin signaling; auxin perception; meristem; vein patterning; leaf expansion; root elongation; seed development; rice fecundity

\section{Introduction}

The rice plant (Oryza sativa L.) is one of the most important crops in the world and serves as a staple food source for over half of the global population. There is an ongoing effort to characterize genes with functions in developmental processes that impact economically important quantitative traits such as shoot and root size, leaf width, number of panicles, seeds per panicle, and seed size. There are also efforts to engineer rice with $\mathrm{C} 4$ traits such as high vein density and high rate of photosynthesis in leaf vein bundle sheath cells to reduce photorespiration [1,2]. The plant hormone auxin plays a role in many of these developmental programs since it regulates cell division and expansion, meristem development, and vascular patterning [3-5]. In recent times, it has become clear that the formation of an embryo, leaves, and roots depend on the generation of local auxin maxima by polar auxin transport [6-8].

Auxin mediates growth and development by regulating the expression of auxinresponsive genes [9]. Although the auxin signaling pathway is simple, involved core proteins are represented by large gene families, allowing for a wide range of context-dependent cellular responses [10-13]. The main components of auxin signaling have been studied intensely in Arabidopsis thaliana L. and involve three protein families: the F-box TRANSPORT 
INHIBITOR RESPONSE 1/AUXIN SIGNALING F-BOX PROTEIN (TIR1/AFB) auxin coreceptors, the AUXIN/INDOLE-3-ACETIC ACID (AUX/IAA) transcriptional repressors, and the AUXIN RESPONSE FACTOR (ARF) transcription factors [9,14-16].

Auxin regulates the transcription of downstream genes by mediating the binding of AUX/IAA transcriptional repressors to F-box TIR1/AFB proteins in the SCFTIR1/AFB complex $[9,13,17]$. This interaction promotes poly-ubiquitination of AUX/IAA proteins and degradation via the $26 \mathrm{~S}$ proteasome $[12,14,15,18]$. In the absence of AUX/IAA repressors, ARFs can homodimerize and activate or repress transcription by binding to auxin responsive elements (AuxREs) in target genes $[16,19,20]$. Both the motif binding preference and the positional relationship of repetitive AuxREs contribute to the specificity in auxin response [17-19]. ARF proteins can also recruit protein complexes that lead to a switch from closed to open chromatin [20], and bind transcription factors from other protein families, integrating auxin signaling with other hormones and environmental signals [21].

Based on loss-of-function mutants, ARF transcription factors play pivotal roles in embryo, root, leaf, flower, and vascular development in A. thaliana [22-32] and are also involved in responses to abiotic and biotic stressors [10,33-35]. The rice (Oryza sativa L.) genome contains 25 Oryza sativa AUXIN RESPONSE FACTOR (OsARF)-encoding genes [36,37]. Mutant phenotypes have been described for several rice OsARF genes. Plants expressing anti-sense OsARF1 mRNA exhibit low vegetative growth, curled leaves, and sterility [38]. T-DNA insertional mutants of osarf12 and osarf16 display dwarfism, abnormal root growth and loss of phosphate and iron homeostasis [39-42]. Rice osarf18 mutants show reduced stature, abnormal cell differentiation, and incomplete seed filling [43]. Mutants in the OsARF24 gene have reduced height and leaf width, combined with distorted leaf phyllotaxy and flag-leaf angle [44]. Loss of OSARF19 function results in enlarged vegetative organs and abnormal flowers [45], while overexpression indicated a role in tillering angle via regulation of OsGH3-5 and BRI1 [46]. Furthermore, repression of OsARF12, 16, 17, and 25 results in increased leaf inclination $[47,48]$. As in A. thaliana, microRNAs modulate levels of rice ARF transcripts $[47,49,50]$.

The OsARF11 gene [37] is known to be expressed at higher levels in the shoot apical meristem, developing panicles, calli, and at lower levels in developing leaves, roots, and seeds [51-53], suggesting that it may play a role in the development of these structures. OsARF11 is also the closest rice homolog of the MONOPTEROS/ARF5 gene [37], which has prominent roles in $A$. thaliana development $[9,26,31,54,55]$. In this study, we assessed the function of OsARF11 by a systematic comparison of osarf11 insertion mutants with wildtype background plants during development. We show that the OsARF11 gene contributes to the development of all assessed organs and leaf veins and that the mutants have reduced responses to auxins.

\section{Results}

\subsection{Genotype of OsARF11 Mutant Plants}

Two independent mutants in the OsARF11 gene (accession no. Os04g0664400) were obtained from the Taiwan Rice Insertional Mutant (TRIM) [49] and the TOS-17 transposon [50] populations. PCR, using primers matching the OsARF11 gene and inserted DNA, and subsequent sequencing of amplicons (Figures S1-S3) confirmed that a T-DNA is inserted in exon 11 of the OsARF11 open reading frame (hereafter osarf $11^{\text {TRIM }}$ mutant allele), while the TOS-17 line has a TOS-17 transposon inserted in the fifth exon (osarf $11^{\text {TOS-17 }}$ mutant allele) (TRIM and TOS-17 databases).

We observed that offspring from heterozygous insertion mutants from both alleles segregated approximately 3:1 for tall and shorter plants (data not shown). PCR-based genotyping revealed that shorter plants were homozygous for insertion (Figure S1). The shorter mutant phenotype confirmed unquantified observations by insertion mutant providers available at their websites. Mutant phenotypes were only observed in plants genotyped as homozygous for mutant alleles, consistent with recessive loss-of-function alleles. Real-Time quantitative PCR indicated that the OsARF11 transcript spanning the insertion site was 
present in wildtype seedlings and absent in seedlings homozygous for mutant alleles (data not shown). While homozygous osarf $11^{\text {TRIM }}$ mutants showed reduced fecundacy, homozygous osarf $11^{\text {TOS-17 }}$ mutants were completely sterile. Since osarf $11^{\text {TRIM }}$ mutants could be maintained as homozygous populations, we first show multiple angles of analysis of this line, followed by an analysis of traits that overlap in plants genotyped as homozygous for the osarf $11^{T O S-17}$ allele.

\subsection{Morphology of OsARF11 ${ }^{\text {TRIM }}$ Mutant Plants}

\subsubsection{Seedlings}

We repeatedly saw a range of slender and short shoots, also known as culms, companioned by dwarfed root systems in osarf $11^{T R I M}$ seedlings relative to corresponding wildtype background (Figure 1A). Since size variation occurs also in wildtype seedlings, we used discrete size categories to assess 119 wildtype and 101 osarf $11^{\text {TRIM }} 14$-day-old seedlings (Figure 2A). The osarf $11^{\text {TRIM }}$ population had fewer tall and above-average height seedlings, and about the same number of average-sized seedlings relative to the wildtype population. The largest difference was in the dwarf categories, where many more mutants than wildtype were classified as having dwarf stature; $14 \%$ mutant seedlings were extreme dwarfs whereas none of the wildtype seedlings fell into this category. While $0.8 \%$ wildtype seedlings presented a shoot-less phenotype, $10 \%$ mutant seedlings showed this phenotype. When the same populations were categorized based on the most recent leaf to emerge, we saw a skewing that indicated delayed emergence in mutants (Figure 2B). In both populations, leaf five was the most common leaf to have emerged; however, the mutant population had $6 \%$ seedlings and wildtype $20 \%$ seedlings with leaf six emerged, and the mutant population had more seedlings with leaf four, three, and two as the most recently emerged.

Two-week-old osarf $11^{T R I M}$ seedlings were, on average, 38\% lighter than wildtype seedlings, a reduction that, when assessed in a subpopulation, was approximately evenly distributed in shoots and roots (Table S1). Shoots of osarf $11^{\text {TRIM }}$ seedlings were $25 \%$ shorter than wildtype shoots. At the same time, mutant leaves two, three, and four had leaf blades that were $22 \%, 21 \%$, and $36 \%$ shorter than their respective wildtype blades. Mutant leaves two, three, and four also had $17 \%, 19 \%$, and $21 \%$ less-wide blades compared to wildtype. Mutant plantlets displaying extreme dwarfism did not survive the transfer to clay media and were not included in adult phenotype scoring. Thereafter and throughout development, the most conspicuous and consistent phenotype of osarf $11^{\text {TRIM }}$ shoots was a $17-21 \%$ narrower leaf width relative to wildtype plants (Table S1). As osarf $11^{\text {TRIM }}$ plants matured, we found in two trials no significant difference in both plant height and shoot biomass, suggesting plants defective in OsARF11 eventually catch up to its wildtype counterparts (Table S1). However, in a third trial, osarf $11^{T R I M}$ plants were significantly shorter (Figure S4), suggesting that this trait may vary with growth conditions. 


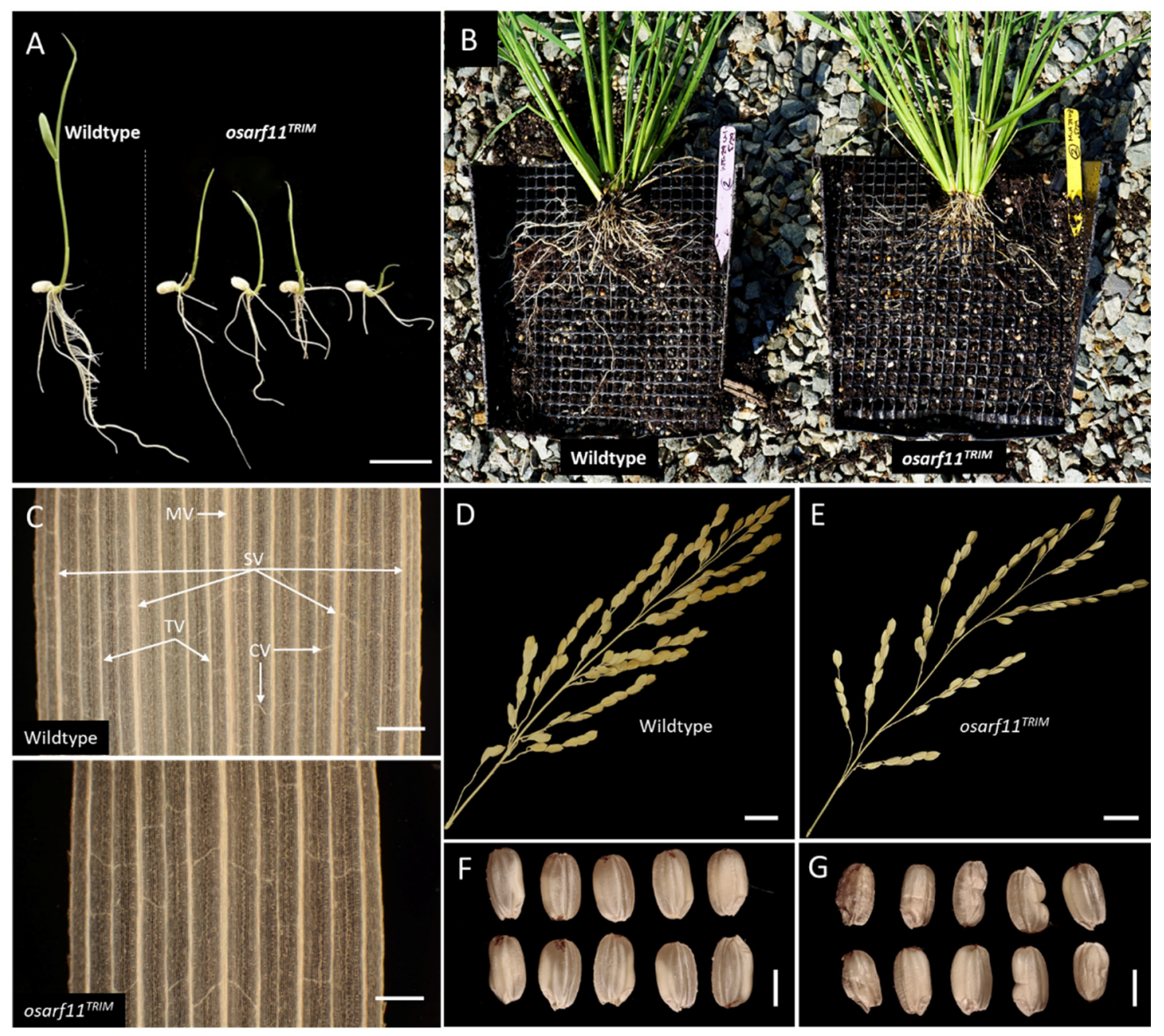

Figure 1. Phenotypes observed in osarf11 1 TRIM plants. (A) Common shoot and root phenotypes of 10-day old osarf11 $1^{\text {TRIM }}$ seedlings. (B) Root growth of four-month-old adult plants. (C) Cleared segment, widest region of leaf blade, three-week-old wildtype (top) and osarf11 ${ }^{\text {TRIM }}$ (bottom) seedlings. Leaf venation classes; $\mathrm{MV}$, midvein; $\mathrm{SV}$, secondary vein; $\mathrm{TV}$, tertiary vein; $\mathrm{CV}$, commissural vein. Dried adult panicles and seeds harvested from (D) wildtype and (E) osarf11 ${ }^{\text {TRIM }}$ plants. Range of seed morphologies observed in $(\mathbf{F})$ wildtype and $(\mathbf{G})$ osarf $11^{\text {TRIM }}$ plants. Scale bars: $(\mathbf{A})=15 \mathrm{~mm}$, (C) $($ top) $=0.3 \mathrm{~mm},(\mathbf{C})($ bottom) $=0.3 \mathrm{~mm},(\mathbf{D})$ (top) and (E) (top) $=10 \mathrm{~mm},(\mathbf{D})$ (bottom), and (E) (bottom) $=3 \mathrm{~mm}$.
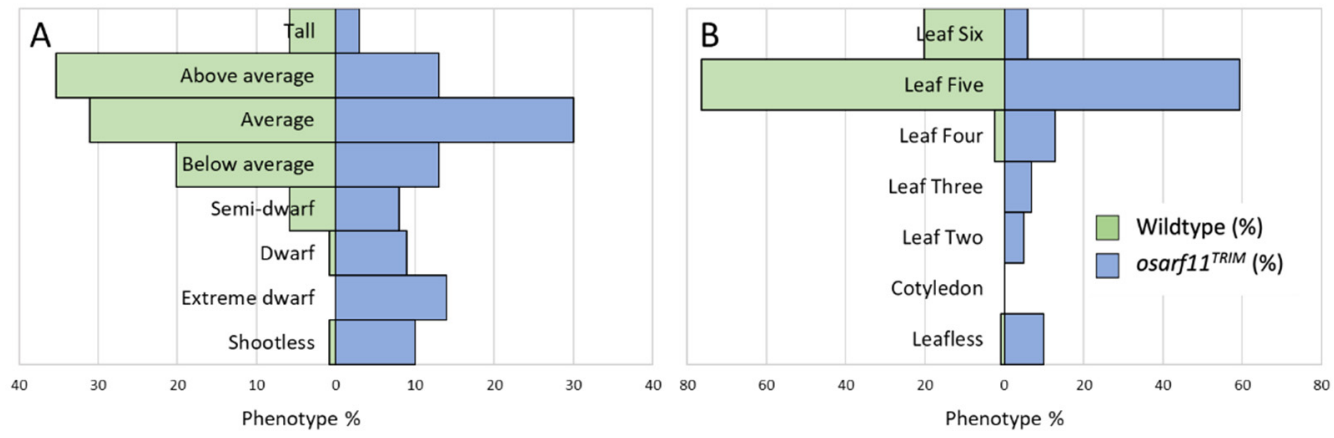

Figure 2. Seedling shoot size phenotype categories of 119 wildtype and 101 osarf11 ${ }^{\text {TRIM }} 14$-dayold seedlings. (A) Shoot size groups based on the following criteria: tall $>135 \mathrm{~mm}$, above average $=116-135 \mathrm{~mm}$, average $=91-115 \mathrm{~mm}$, below average $=66-90 \mathrm{~mm}$, semi-dwarf $=41-65 \mathrm{~mm}$, dwarf $=20-40 \mathrm{~mm}$, extreme dwarf $<20 \mathrm{~mm}$, leafless = no above ground organs. (B) Most recently emerged leaf primordia as observed under stereo microscope. 


\subsubsection{Roots}

Rice has a root system that develops post-embryonically and consists of seminal, crown, and lateral roots. We compared root growth in germinating osarf $11^{T R I M}$ and wildtype seedlings. After one week of growth, we observed that $o s a r f 11^{\text {TRIM }}$ seedlings had primary roots that were $27 \%$ shorter, had $26 \%$ fewer crown roots, and $64 \%$ fewer lateral roots relative to wildtype seedlings (Figure $3 \mathrm{~A}-\mathrm{C}$ ). Although variable, the reduced root growth in the osarf $11^{T R I M}$ line remained a consistent phenotype (Figure 1B). The dried root system of adult osarf $11^{\text {TRIM }}$ plants weighed, on average, 33\% less than that of wildtype plants (Figure 3H).
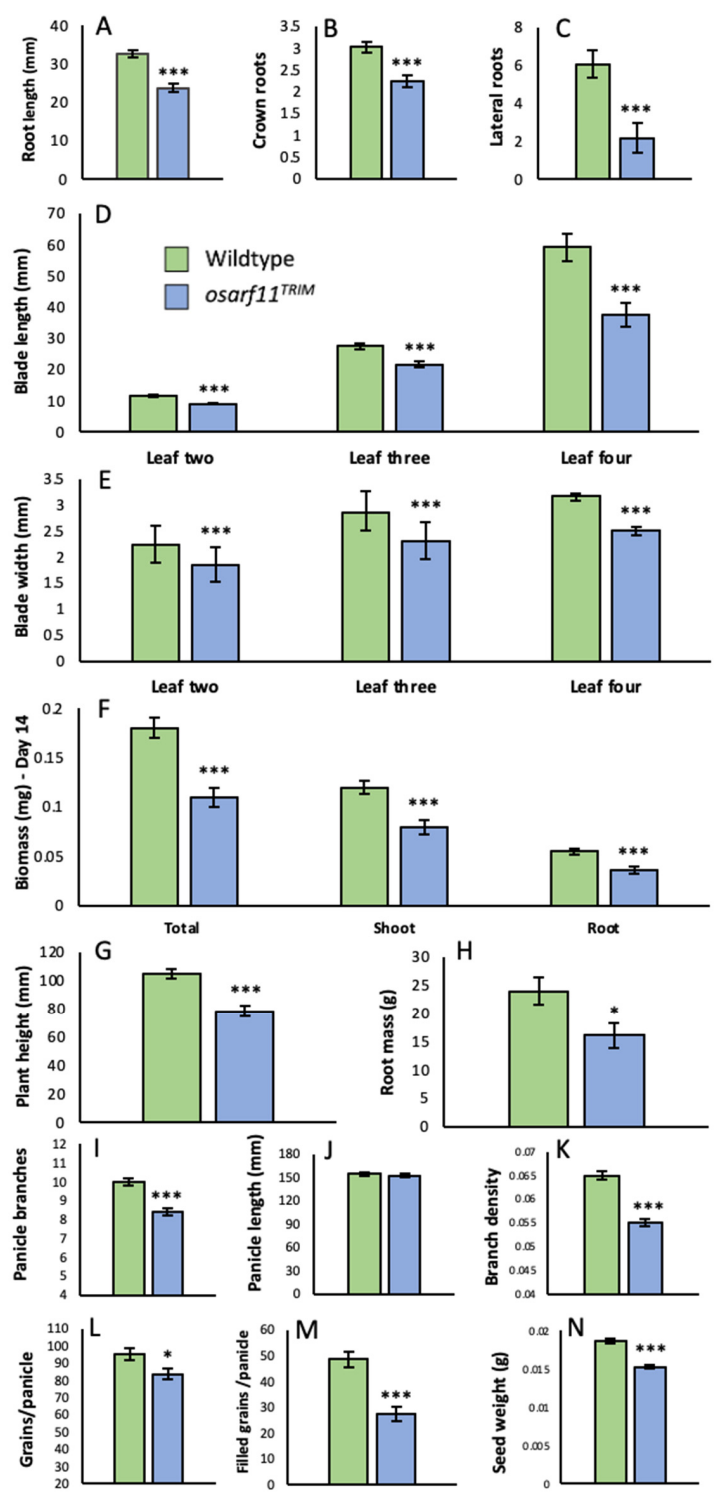

Figure 3. Quantitative phenotypes observed in osarf11 ${ }^{T R I M}$ plants. (A) Primary root length, (B) crown root number, and (C) lateral root number in seven-day-old seedlings. (D) Blade length and (E) blade width measured at day 14 of development in leaves two, three, and four of the primary shoots. (F) Plant weight and (G) plant height of 14-day old seedlings. (H) Dry root weight of six-monthold adult plants. (I) Panicle branch number, (J) panicle length, and (K) panicle branch density of dried adult panicles. Branch density = number of panicles/panicle length. (L) Total grain number harvested per panicle. (M) Number of filled grains per panicle. (N) Average seed weight. Asterisks indicate significant differences between wildtype and mutant categories (Student's $t$ test; * $p<0.05$, $* * * \quad p<001)$. Error bars $=$ standard error. 


\subsubsection{Panicle and Seed Development}

Three independent trials revealed a significant decrease in the number of lateral panicle branches along the main panicle axis (Figure 3I). Since the panicle length from first branch to the apex did not differ between wildtype and mutant plants, the reduced number of branches also translated into a reduction in branch density in osarf $11^{T R I M}$ plants relative to wildtype (Figure 3K). Mutant osarf $11^{T R I M}$ plants developed $12 \%$ fewer grains per panicle compared to wildtype (Figure 3L). When plants of osarf $11^{T R I M}$ and wildtype plants were grown side by side, we observed about $45 \%$ fewer filled grains per panicle in osarf $11^{\text {TRIM }}$ mutant plants (Figure 3M). Additionally, osarf $11^{T R I M}$ seeds were $17 \%$ lighter (Figure $3 \mathrm{~N}$ ), shorter, less wide, and thinner than corresponding wildtype seeds (Table S1).

\subsection{Leaf Vascular Pattern Formation Is Altered in osarf11 Mutants}

\subsubsection{Vein Number and Density}

To assess a potential role of OSARF11 in vascular patterning, we counted longitudinal veins in cleared second, third, and fourth leaves of the primary shoot in wildtype and osarf11 ${ }^{\text {TRIM }}$ populations. Mutant leaves had $17-28 \%$ fewer longitudinal veins (Figure $4 \mathrm{~A}$ ). When the number of veins per mm width of the blades was calculated, we observed a reduction in vein density in leaf three and four but not two in osarf1 $11^{\text {TRIM }}$ mutants. The reduction in vein density was most obvious in developing leaves but was also present in fully grown leaves. At two weeks, osarf $11^{\text {TRIM }}$ showed an average $7 \%$ reduction in longitudinal vein density in the third leaf and a $9 \%$ reduction in leaf four (Figure $4 \mathrm{~B}$ ). In a separate population scored at three weeks, a reduction of $5 \%$ and $6 \%$ was detected in the third and fourth leaf, respectively (Table S2). Floral organ vasculature was also assessed, but no abnormalities were observed (data not shown).

\subsubsection{Tertiary Veins}

In addition to the single midvein, we observed that the number of thicker secondary veins was invariable at four in the second, third, and fourth leaves of wildtype and mutant seedlings. This suggests that the difference in vein number between the two genotypes were in the number of tertiary veins. Counting of tertiary veins showed that mutant second, third, and fourth leaves had on average $27 \%, 33 \%$, and $29 \%$ fewer tertiary veins than respective wildtype leaves (Figure $4 \mathrm{C}$ ). We also directly measured the distance between tertiary veins and found it to be significantly higher in the fourth leaf of two and threeweek-old mutant leaves relative to wildtype (Figure $4 \mathrm{D}$ ). Tertiary veins evaluated in the fourth leaf were also found to initiate further from the leaf tip in osarf11 ${ }^{T R I M}$ compared to wildtype plants in both two and three-week-old seedlings (Figure 4E, Figure S5).

\subsubsection{Commissural Veins and Areole Size}

When distance between transversal commissural veins was measured directly, the average distance was highly variable. However, when the number of commissural veins were counted across the widest part of the leaf width, the results showed that the commissural vein density was $12 \%$ (2-week-old) and 15\% (3-week-old) lower in the fourth leaf of osarf $11^{\text {TRIM }}$ mutants than corresponding wildtype leaves (Figure $4 \mathrm{~F}$ ). We also measured the area enclosed by two longitudinal veins and two commissural veins. The areole size was 27\% (2-week-old; Figure 4H) and 37\% (3-week-old; Table S2) larger in the fourth leaf of mutant seedlings relative to wildtype seedlings. 

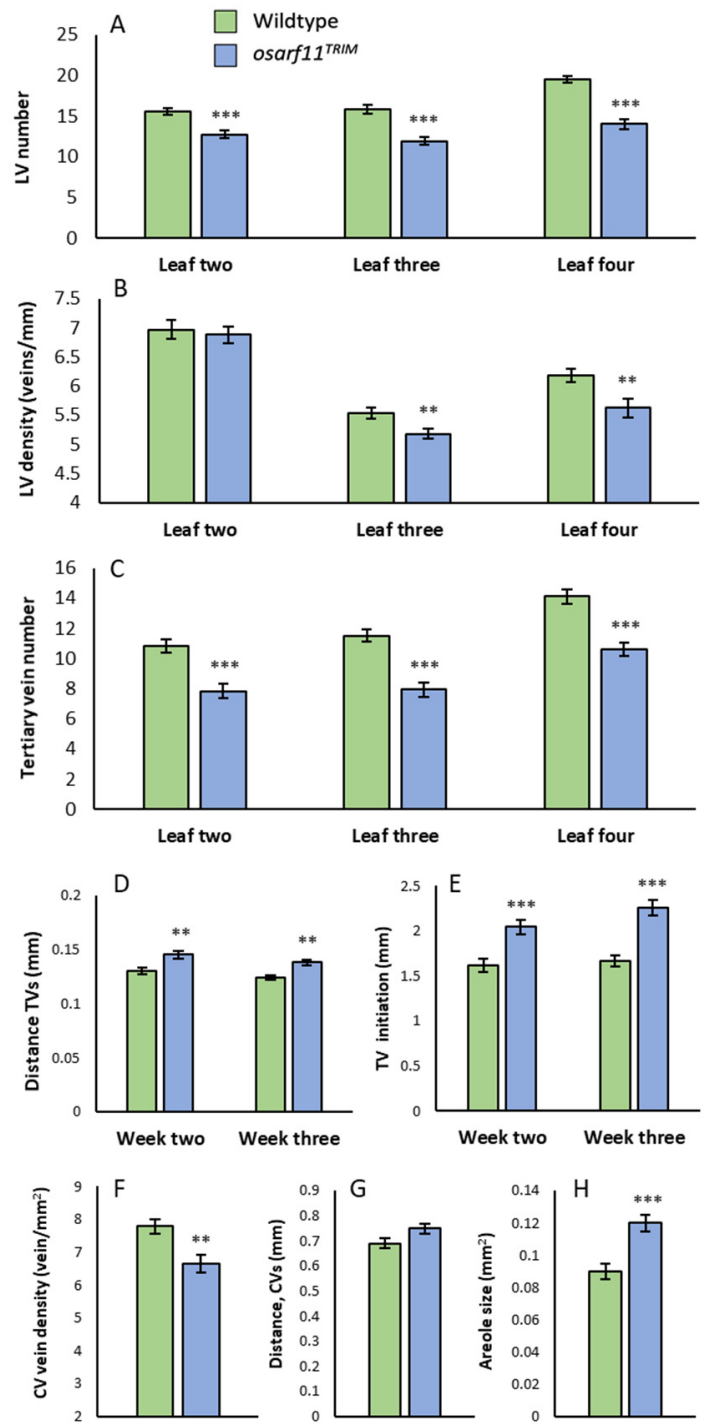

Figure 4. Leaf venation defects in OsARF11 TRIM seedlings. (A) Longitudinal vein number, (B) longitudinal vein density, and (C) tertiary vein number in leaves two, three, and four of the primary shoot. (D) Average distance between tertiary veins, measured at the widest part of leaf four at week two and three of development. Each data point represents an average of three distances measured per leaf scored. (E) Tertiary vein initiation, measured from the tip, in leaf four at week two and three. (F) Commissural vein density; number of veins per leaf area, measured at the widest part of leaf four. (G) Distance between two adjacent commissural veins and $(\mathbf{H})$ areole size in leaf four. Each data point in $(\mathbf{G}, \mathbf{H})$ represents an average of 10 measurements per leaf. Asterisks indicate significant differences with respect to wildtype (Student's $t$ test; ${ }^{* *} p<0.01,{ }^{* * *} p<0.001$ ). Error bars $=$ standard error. $L V$, longitudinal veins; $T V$, tertiary veins; $C V$, commissural veins.

\subsection{Morphometric Analyses of OsARF11 ${ }^{\text {TOS-17 Mutants }}$}

To complement the analysis of osarf $11^{\text {TRIM }}$, we also conducted pairwise comparison of wildtype and homozygous TOS-17 insertion mutant (osarf11 ${ }^{\text {TOS-17 }}$ ). Just as in osarf $11^{\text {TRIM }}$ mutants, we observed that self-fertilized heterozygous osarf $11^{\text {TOS-17 }}$ plants segregated dwarf seedlings. As described above, we focused our quantification of the heterogeneous phenotype on homozygous osarf $11^{\text {TRIM }}$ mutant populations. Unlike osarf $11^{\text {TRIM }}$ though, the reduced stature in osarf $11^{\text {TOS-17 }}$ mutants remained consistent, manifesting in, on average, $15 \%$ shorter shoots in adult plants (Figure 5A). The primary root was $31 \%$ shorter in osarf $11^{\text {TOS-17 }}$ in three-week old seedlings and the root system had $47 \%$ fewer lateral roots (Figure $5 \mathrm{~B}, \mathrm{C}$ ) and $12 \%$ fewer crown roots (Table S3). We saw a comparable reduction 
in width of leaves in osarf11 ${ }^{\text {TRIM }}(17-21 \%)$ and osarf11 ${ }^{\text {TOS-17 }}(14-26 \%)$ relative to corresponding wildtype backgrounds (Figure 3E, Figure 5D). This defect was companioned by a comparable reduction in vein number in osarf11 ${ }^{\text {TRIM }}(17-21 \%)$ and osarf $11^{\text {TOS-17 }}(16-19 \%)$ (Figure 4A, Figure 5E).
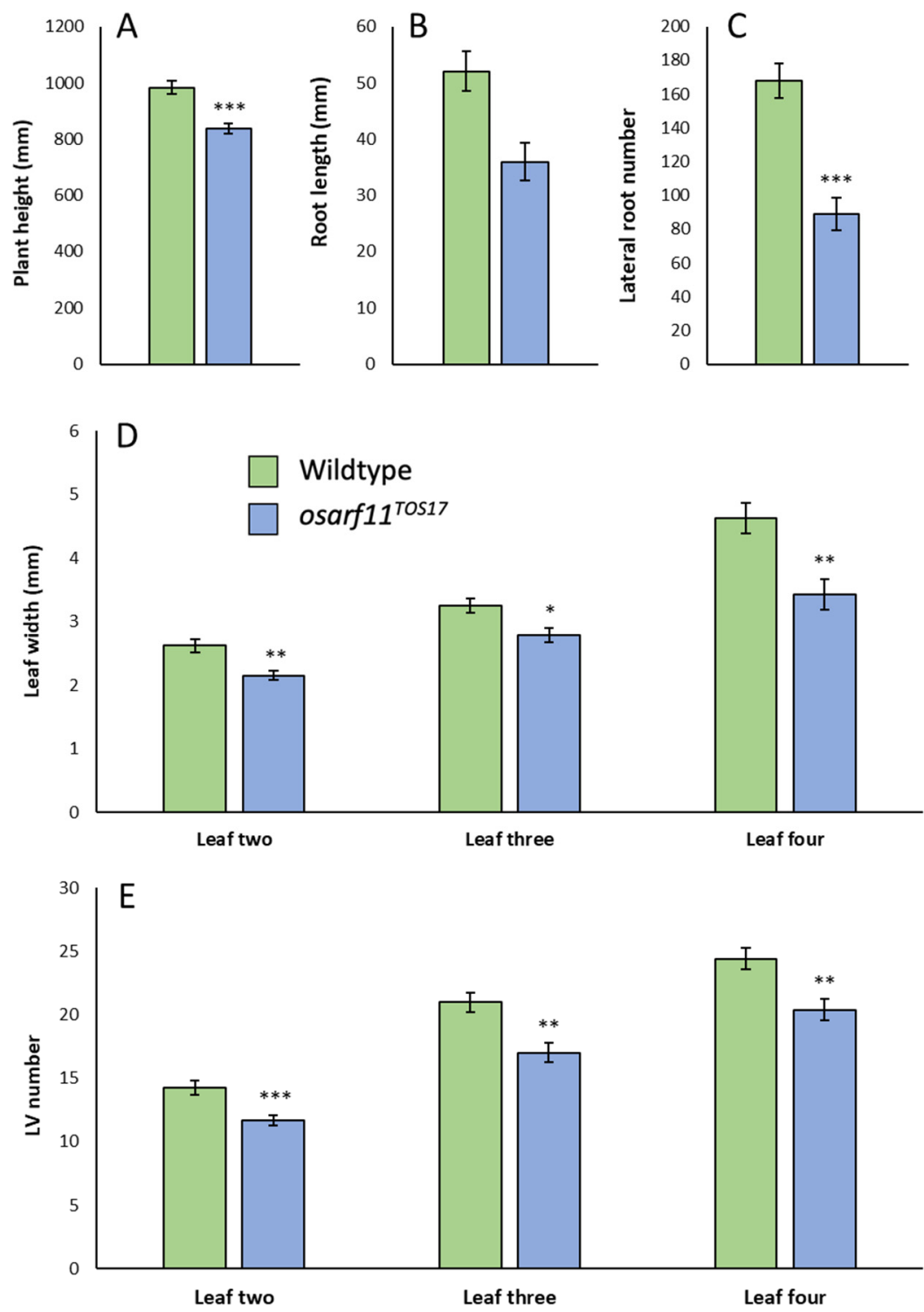

Figure 5. Quantitative phenotypes observed in osarf11 ${ }^{\text {TOS-17 }}$ plants. (A) Plant height of three-monthold adult plants. (B) Primary root length and (C) lateral root number in three-week-old seedlings. (D) Leaf width and (E) longitudinal vein, $L V$, number measured in leaves two, three, and four of the primary shoot. Asterisks indicate significant differences with respect to wildtype (Student's $t$ test; $\left.{ }^{*} p<0.05,{ }^{* *} p<0.01,{ }^{* * *} p<0.001\right)$. Error bars $=$ standard error.

\subsection{Loss of OsARF11 Results in Reduced Auxin Perception}

\subsubsection{Callus Induction}

Exogenous application of the synthetic auxin 2,4-Dichlorophenoxyacetic acid (2,4-D) results in artificial callus induction in in vitro culture in various plant species. To assess if the OsARF11 contributes to this auxin response in rice, we evaluated callus induction from germinating seeds. After two weeks on 2,4-D-containing media, germinating osarf $11^{\text {TRIM }}$ seeds had a $28 \%(1 \mathrm{mg} / \mathrm{L} 2,4-\mathrm{D})$ and $21 \%(2 \mathrm{mg} / \mathrm{L} \mathrm{2,4-D)} \mathrm{reduced} \mathrm{incidence} \mathrm{of} \mathrm{calli}$ (Figure 6A). We also documented, on average, $41 \%$ (1 mg/L 2,4-D) and $31 \%$ (2 mg/L 2,4-D) 
less callus produced from osarf $11^{\text {TRIM }}$ seeds relative to wildtype seeds (Figure 6B). After four weeks of growth, proliferating calli from both genotypes were re-plated on shoot induction media with a high cytokinin concentration. We observed no visual difference in the ability to regenerate shoots between the genotypes.

A

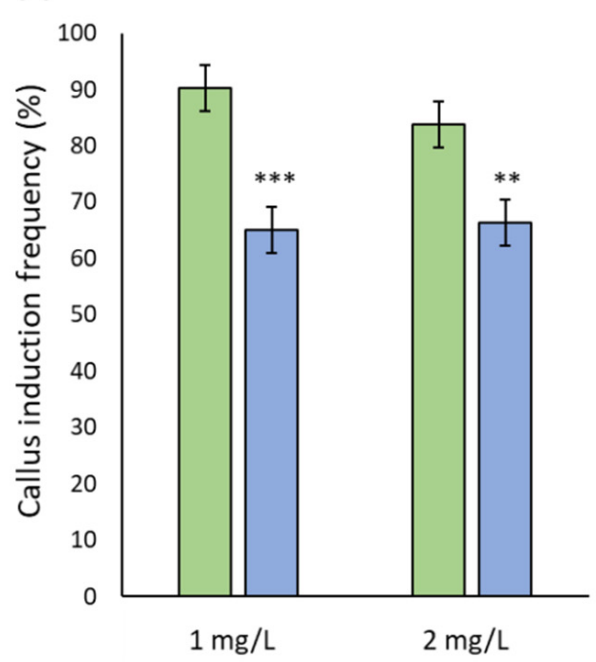

B

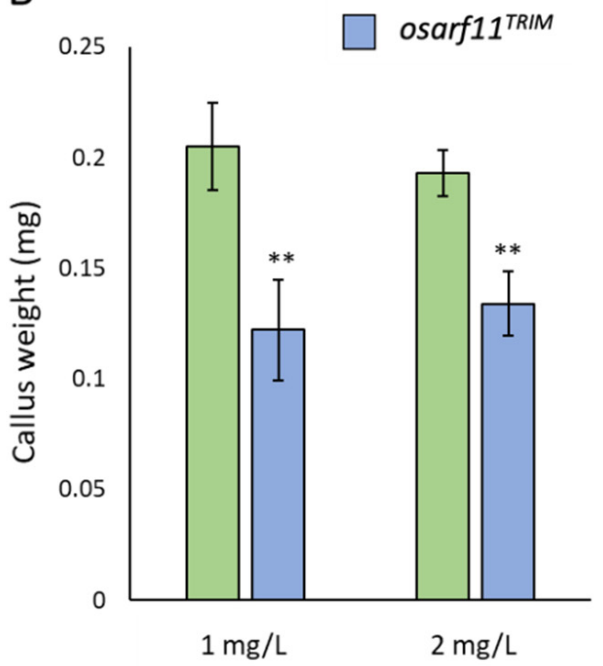

Figure 6. Callus induced from osarf11 1 TRIM and wildtype seeds with 2,4-Dichlorophenoxyacetic acid (2,4-D). (A) Callus induction frequency. Each column represents the average frequency of five trials. Callus induction frequency $(\%)=$ number of seeds producing callus/number of seeds inoculated $\times 100$. (B) Weight of seed-induced calli after four weeks of 2,4-D exposure. Asterisks indicate significant differences with respect to wildtype (Student's $t$ test; ${ }^{* *} p<0.01,{ }^{* * *} p<0.001$ ). Error bars $=$ standard error.

\subsubsection{IAA Applications}

The effect of exogenous IAA on developing tissues during early root development was evaluated in osarf $11^{\text {TRIM }}$ plants relative to wildtype. Since roots of wildtype and mutant seedlings differ in length and number (Figure $3 \mathrm{~A}-\mathrm{C}$ ), we measured the change in growth during the test period rather than resulting phenotypes. After seven days of IAA exposure, the growth of wildtype primary roots was inhibited by $72 \%(0.5 \mu \mathrm{M}$ IAA), and $76 \%(1.0$ $\mu \mathrm{M}$ IAA) relative to the control untreated wildtype plants (Figure 7A). The response of mutant seedlings differed in that $0.5 \mu \mathrm{M}$ IAA inhibited primary root growth by only $40 \%$, and $1.0 \mu \mathrm{M}$ IAA was required to observe an effect comparable (77\%) to $0.5 \mu \mathrm{M}$ IAA in wildtype roots. Growing the plants in $0.5 \mu \mathrm{M}$ IAA resulted in a significant increase in the number of crown roots in wildtype seedlings but not in osarf11 ${ }^{\text {TRIM }}$ seedlings (Figure 7A). Treatment with $1.0 \mu \mathrm{M}$ IAA resulted in an insignificant increase in crown root number in both genotypes.

\subsubsection{Phenylboronic Acid Exposure}

In vitro analysis has showed that phenylboronic acid treatment can phenocopy mp/arf5 phenotypes by inhibition of polar auxin transport [56]. We applied phenylboronic acid (PBA) to germinating wildtype and osarf $11^{T R I M}$ plants to assess its effect on vein formation. In leaves two, three, and four of wildtype seedlings, exposure to 12.5 and $25 \mu \mathrm{M}$ PBA resulted in a significant decrease in the number of longitudinal veins (Figure 7B). No such effect was seen in osarf $11^{\text {TRIM }}$ seedlings. 

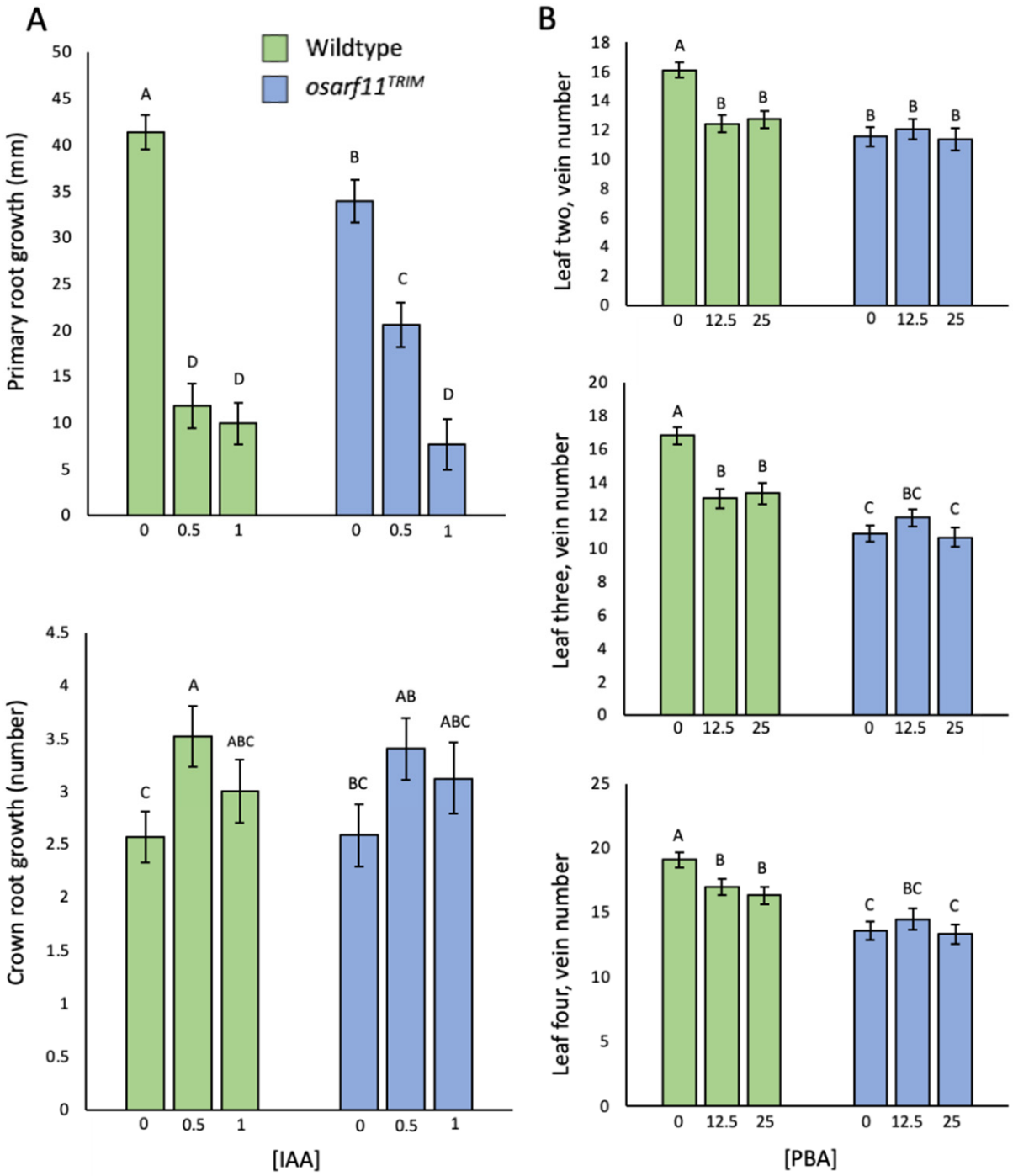

Figure 7. The effect of exogenous auxin and phenylboronic acid (PBA) exposure during early development. (A) Shoot and root growth following a seven-day exposure to indole-3-acetic acid (IAA) $(0,0.5,1 \mu \mathrm{M})$ in wildtype and osarf $11^{\text {TRIM }}$ seedlings. (B) Longitudinal vein development in the presence of PBA $(0,12.5,25 \mu \mathrm{M})$. Statistical significance was determined using a pair-wise Student's $t$ test. Columns not represented by the same letter, were found to be significantly different. Error bars $=$ standard error.

\subsection{Gravitropism}

As root gravitropism depends on both carrier-mediated asymmetric distribution of auxin in the roots and auxin-mediated cell expansion [57,58], we evaluated the effect of a $90^{\circ}$ shift in orientation in osarf $11^{\text {TRIM }}$ and wildtype roots (Figure 8). Root tip angles were variable amongst both genotypes, but on average, wildtype plants showed a root tip angle of $63.24^{\circ}$ and osarf $11^{\text {TRIM }}$ a root tip angle of $51.7^{\circ}$, which translates into a $18 \%$ reduction in root curvature $(p=0.0034)$ relative to wildtype. 

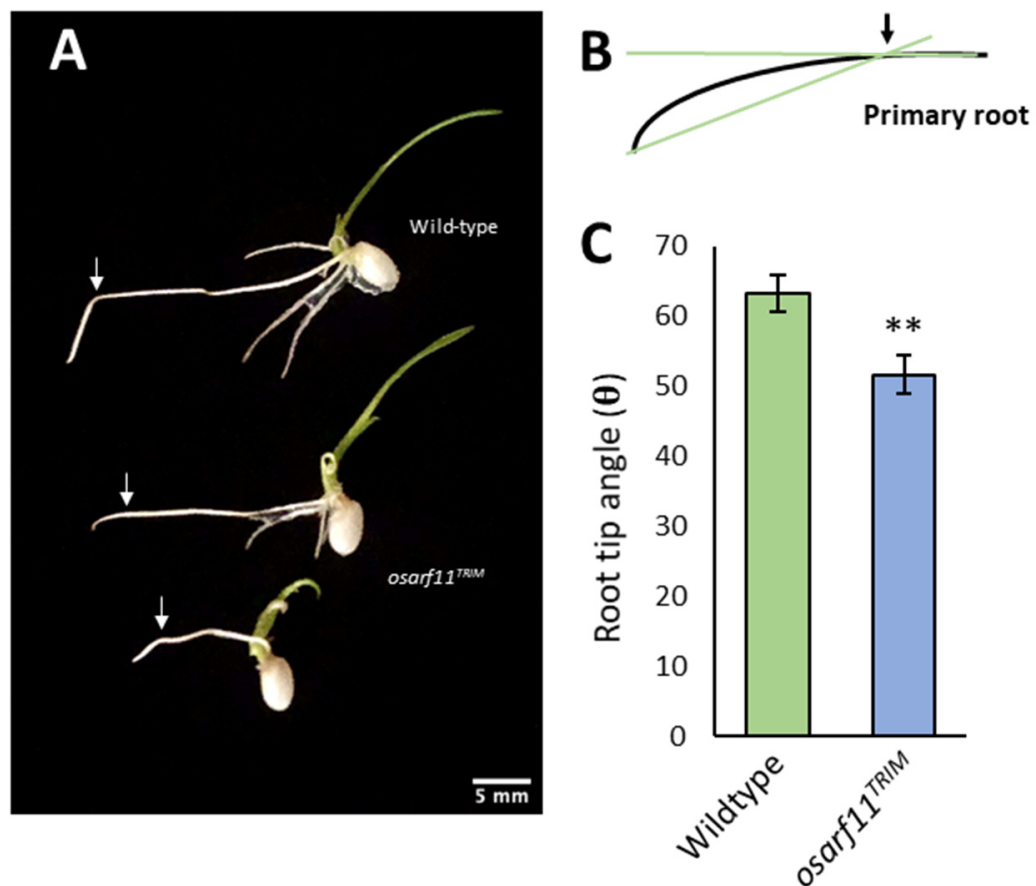

Figure 8. Root gravitropic response in osarf $11^{T R I M}$ and wildtype seedlings. (A) Wildtype and osarf11 ${ }^{\text {TRIM }}$ seedlings were grown vertically for six days under normal growth conditions, followed by a $90^{\circ}$ rotation. Arrows in (A) indicate root tip position at time of rotation, which is used as a base to measure angle of reorientation after $24 \mathrm{~h}$ of growth (B). Mean root tip angle (C). Data from three independent trials were pooled; wildtype, $\mathrm{n}=46$; osarf11 ${ }^{T R I M}, \mathrm{n}=38$. Asterisks indicate significant differences with respect to wildtype (Student's $t$ test; ${ }^{* *} p<0.01$ ). Error bars $=$ standard error.

\section{Discussion}

In this study, we have assessed the phenotypes of plants that are homozygous for insertions in the OsARF11 gene. The two alleles, generated by independent insertions, resulted in a range of similar phenotypes in homozygous mutants. In addition, many of these traits have been linked to auxin before, including the narrow leaf, which has been described in an osarf11 mutant, a mutant defective in auxin biosynthesis, and a mutant defective in auxin transport $[54,55,59]$. Thus, we find it likely that the observed phenotypes are due to the loss of the OsARF11 function. The two alleles differ in the degree of fertility, though, as osarf $11^{\text {TRIM }}$ produces $45 \%$ fewer seeds per panicle than wildtype plants and homozygous osarf $11^{\text {TOS-17 }}$ mutants do not produce any seeds. Since the osarf11 $1^{\text {TOS-17 }}$ insertion is in the fifth exon, and the osarf11 $1^{\text {TRIM }}$ insertion is in the eleventh exon, it is possible that the latter is a weak allele or interferes with gene function differently than the osarf11 ${ }^{\text {TOS-17 }}$ allele. Both alleles, however, have insertions in the region encoding the amino-terminal DNA-binding domain, truncating both the central activation domain and the carboxy-terminal dimerization domains, indicating that both are null alleles. The TOS-17 line is known to carry seven transposon copies, of which only two are inserted in predicted genes, OsARF11 and OsTMF. Homozygous ostmf mutants do not show reduced fertility or other defects characterized here [60], indicating that the increased infertility in the TOS-17 line is not due to a defect in the OsTMF gene. An alternative explanation is that osarf11 effect on fertility is more penetrant in the TOS-17 genome background than in the TRIM background. This explanation seems likely since the mutants differ only quantitatively for this trait. The identification and analysis of additional osarf11 mutant alleles may be the easiest way of addressing the function of OsARF11 in fertilization and early embryo development.

We observed osarf11 phenotypes that can be summarized as reduced size, reduced number of meristems, fewer veins, fewer seeds, and reduced perception of auxin. Here, we 
will address these phenotype classes and the role that OsARF11 may play in corresponding developmental processes. The reduced growth of roots and leaf blade, both in length and width, taken together with the reduced response to exogenous auxin, both in incidence of callus formation and growth of calli, are consistent with a role of OsARF11 in mediating a response to auxin to stimulate cell division, cell expansion, or both. Likewise, we observed that osarf11 mutants had reduced response to concentrations of IAA that inhibit root elongation, indicating that OsARF11 plays a role in auxin-mediated root cell elongation. Auxin is one of the main activators of both cell division and cell expansion [3]. Although evidence for a direct role of ARFs in these processes is sparse [3,61], reduced size of organs is a reoccurring theme in rice arf mutants [38,41,43-45] and these genes could have both unique and overlapping functions in the regulation of cell division and elongation. The $d s 1$ rice dwarf mutant is defective in a gene similar to the A. thaliana EMBRYONIC FLOWER 1 (EMF1) gene [53]. Yeast-two-hybrid experiments show that DS1 proteins interact with OsARF11 and other proteins and both DS1 and OsARF11 proteins localize to nuclei [53]. This interaction suggests that miss-regulation of OsARF11 may be part of the $d s 1$ dwarf phenotype. The $d s 1$ mutants are also insensitive to brassinosteroids, which in part appears to be mediated by OsARF11, as expression of the brassinosteroid receptor OsBRI1 is reduced in osarf11 mutants and OsARF11 can bind to AuxREs in the OsBRI1 promoter [54] Thus, there is already evidence that OsARF11 influence growth by increasing sensitivity to brassinosteroid growth hormones.

We observed several instances in which fewer meristem-derived organs formed in the osarf11 mutants. First, fewer crown and lateral roots formed in osarf11 seedlings. Second, mutant panicles formed fewer branches, and branches had fewer grains. These phenotypes are consistent with the relatively high level of OsARF11 expression in developing roots, shoot apical meristem, and young panicles [53]. The reduced panicle branch and grain phenotype is akin to weak alleles of the A. thaliana MP/ARF5 gene, to which OsARF11 is the closest rice homolog based on phylogenetic analysis [37]. While strong mp/arf5 alleles do not form an embryonic root, and after induction of roots, form inflorescences with no flowers, weak alleles form a reduced root system and fewer flowers relative to wildtype plants [22]. OsARF19 contributes to lateral root formation [62] and OsARF1 regulates the CROWN ROOT-LESS 1 gene [63], providing potential partners for OsARF11 in root meristem development.

Leaves of osarf11 mutants have a normal number of primary and secondary veins, but a reduced number of tertiary and commissural veins. We suggest several potential causes for this difference. First, the reduced venation is a secondary effect of reduced leaf width. Speaking against this option is the parallel increase in vein spacing in mutant leaves. Second, levels of inductive auxin may be limited at the time of tertiary and commissural vein formation, which combined with reduced auxin perception results in fewer higherorder veins in mutant leaves. However, there are A. thaliana mutants with defects in auxin perception, auxin efflux carrier localization, and auxin biosynthesis that have in common more or less extensive gaps in differentiation of late-forming xylem vessels in leaves [22,64-67]. We see no gaps in the continuity of vein vessels in osarf11 mutant leaves (data not shown), speaking against this general explanation. Finally, the two groups of veins differ in their origin of appearance. Major monocot veins extend to the leaf margin [68] and may be initiated in a process involving the epidermis similar to that seen in A. thaliana [8,26]. In contrast, tertiary and commissural veins form internally, between existing veins, and may depend on a modified vein formation process with a higher dependence on OsARF11. We also saw that osarf11 tertiary veins appear further away from the leaf apex than wildtype tertiary veins (Figure 4E and Figure S5), which may be another facet of reduced response to auxin. The reduced number of veins together with the lower vein density is another osarf11 phenotype that is similar to mp/arf5 mutants, albeit not as strong. Although dicot and monocot venation patterns are radically different, the areole area is increased by as much as $37 \%$ in osarf11 leaves (Figure $4 \mathrm{H}$ ), a number comparable to that seen in a weak mp/arf5 allele [22]. The large increase in areole area is probably a compound effect of fewer 
tertiary and commissural veins (Figure 4C,F) and is likely to affect both water supply and removal of photosynthates, which in turn could contribute to other observed reducedgrowth phenotypes. Small areole areas have been linked to acclimation and adaptation to drought stress and reduced sugar accumulation feedback on photosynthesis [69-72], and OsARF11 could thus play an indirect role in these processes. Although MP/ARF5 expression precedes and predicts vein formation $[25,26]$, no such information is available for OsARF11. Treatment of developing A. thaliana embryos with phenylboronic acid (PBA) results in mp/arf5-like seedlings including little or no venation in cotyledons, an effect attributed to disruption of polar auxin transport by internalization of PIN1 auxin efflux carriers [56]. In rice seedlings germinating on PBA-containing media, the effect was much less dramatic, causing reduced numbers of veins in leaves of wildtype seedlings but not osarf11 ${ }^{\text {TRIM }}$ seedlings. In strict genetic terms, the insensitivity suggests that OsARF11 is epistatic to the function inhibited by PBA, possibly a rice PIN1 ortholog, indicating that a function of OsARF11 could be to activate the expression of an OsPIN gene, similar to the MP/ARF5 regulation of PIN1 in A. thaliana [26,73]. Similar to MP/ARF5, there is also evidence that steady-state levels of OsARF11 transcripts increase in response to IAA treatment $[53,74]$, which would allow OsARF11 to respond also on a transcriptional level to local auxin maxima formed during vein and meristem specification.

The reduced fecundity as well as the range of early seedling phenotypes in osarf11 mutants are enigmatic. It is possible that they are all part of a spectrum of stochastic phenotypes caused by auxin signaling instability in the absence of OsARF11. Mutants in the GNOM gene, defective in endosomal recycling needed for polar auxin transport, provide precedent for a situation in which a single gene disruption can result in a wide range of embryo and seedling phenotypes [75,76]. A cursory assessment of osarf11 embryo anatomy, however, did not reveal obvious defects (not shown) and gene expression markers of auxin-related processes and tissues will be needed to understand the role of OsARF11 in embryo development and early seedling growth.

Our analyses provide evidence that OsARF11 contributes substantially to seedling growth, leaf, and root system development. We also saw a $45 \%$ reduction in seed number per plant and a $17 \%$ reduction in seed weight in osarf11 mutants. Differently from the osarf11 alleles in this study, varieties used for breeding are likely to carry functional allele variants of the OsARF11 that differ considerably less in their contribution to important quantitative traits. The fact remains, however, that this study pinpoints a role of OsARF11 in these processes, providing a candidate for selection and targeted modification of rice productivity.

\section{Materials and Methods}

\subsection{Gene Terminology, Mutant Lines, Genotyping, and Growth Conditions}

Upper case indicates wildtype allele, lower case indicates mutant allele. Italic font indicates gene or transcript, and regular font indicates protein. Sequence and annotation for OsARF11 can be found at the Rice Annotation Project Database [77] using accession no. Os04g0664400, National Center for Biotechnology Information using accession no. LOC4337309 or Michigan State University accession no. LOC_Os04g56850.1. This gene is also known as OsARF11-like, OsARF5, and OsMP. Mutant lines containing insertional mutations in the OSARF11 predicted open-reading frame were kindly provided by both TRIM (M0030446, OsARF6) [49] and TOS-17 (NC2659) [50] databases. The sequence information available at the mutant line websites indicate one T-DNA insertion in the M0030446 line and two gene TOS-17 insertions in the NC2659 line, with an overlap only in the OsARF11 gene. The Oryza sativa japonica variety Nipponbare, in which the mutations were introduced, was used as a wildtype control in all comparison studies. DNA was extracted from 14-day-old seedlings using ChargeSwitch gDNA Plant Kit (CS18000, ThermoFisher Scientific, Burlington, ON, Canada). PCR was used to confirm the insertion and identify homozygous mutant plants in segregating populations (Supplemental Figure S1). T-DNA primer 5'-TCGCGATCCAGACTGAATGC-3' and OsARF11 primer 5'-GGGGACTCCCAAGGGTTTGA-3' were used to confirm the insertion of the T-DNA 
in osarf11 ${ }^{\text {TRIM }}$. OsARF11 ${ }^{\text {Tos-17 }}$ primer $5^{\prime}$-CAGAAATATTCAGTGGGGTG-3' and tail6 TOS17 primer $5^{\prime}$-AGGTTGCAAGTTAGTTAAGA-3' were used to confirm the TOS-17 tag in osarf11 ${ }^{\text {TOS-17. }}$.

Morphometric measurements were scored in wildtype, osarf $11^{\text {TRIM }}$, and osarf $11^{\text {TOS-17 }}$ lines. Full seeds were de-husked, and surface sterilized in $70 \%(v / v)$ ethanol for $5 \mathrm{~min}$, followed by $50 \%(v / v)$ commercial bleach with continuous shaking for $30 \mathrm{~min}$ and repeated washes with sterile water. Seeds were dried on sterile filter paper and plated on halfstrength Murashige and Skoog Medium (MS, M5531, PhytoTech Labs Inc., Lenexa KS, USA) supplemented with $30 \mathrm{~g} / \mathrm{L}$ sucrose and $8 \mathrm{~g} / \mathrm{L}$ plant agar (A111, PhytoTech Labs Inc., Lenexa, KS, USA). Plates were incubated in a growth chamber for seven days at $25{ }^{\circ} \mathrm{C}$ with 16/8-h light/dark conditions. Germinated seedlings were transferred to beakers with distilled water containing $0.2 \mathrm{~g} / \mathrm{L}$ NPK 20-20-20 fertilizer for one week followed by potting in clay particle media (Turface MVP, Evergro, Delta, BC, Canada) as described (Eddy et al., 2008.) and moved to a greenhouse. Natural light was supplemented with $600 \mathrm{~W}$ high-pressure sodium lamps up to $12 \mathrm{~h}$ /day and temperature was kept between 20 and $30^{\circ} \mathrm{C}$. Plants were fertilized twice a week, alternating between $2 \mathrm{~g} / \mathrm{L}$ NPK 20-20-20 and $0.2 \mathrm{~g} / \mathrm{L}$ NPK 21-0-0. Mutant seedlings displaying extreme dwarfism and insufficient root development did not survive the transfer to clay media and were not included in adult phenotype scoring.

\subsection{Tissue Culture Assays}

Callus tissue was induced from wildtype and osarf11 ${ }^{\text {TRIM }}$ de-husked seeds plated on full strength MS media supplemented with $30 \mathrm{~g} / \mathrm{L}$ sucrose, $30 \mathrm{mg} / \mathrm{L}$ casamino acids, 2.8 g/L L-proline, 4 g/L phytagel (P8169, Sigma-Aldrich Canada Co., Oakville, ON, Canada) and 1 or $2 \mathrm{mg} / \mathrm{L}$ 2,4-Dichlorophenoxyacetic acid (2,4-D). Media was buffered to a $\mathrm{pH}$ of 5.8. Plates were placed in an incubator set to $30{ }^{\circ} \mathrm{C}$ with approximately $200 \mu \mathrm{mol} \mathrm{m}{ }^{-2} \mathrm{~s}^{-1}$ light intensity and 16-h day length. The frequency of seeds that produced callus were scored after two weeks. Proliferating calli were transferred to fresh media and grown for an additional two weeks, after which their weights were taken. To induce shoots, calli were transferred from media described above, but supplemented with $2 \mathrm{mg} / \mathrm{L}$ Kinetin and $1 \mathrm{mg} / \mathrm{L} \mathrm{NAA}$, instead of 2,4-D. Cultures were transferred to a growth chamber set to $25^{\circ} \mathrm{C}$ with $16 / 8$-h light/dark conditions.

Seven-day-old wildtype and osarf $11^{\text {TRIM }}$ seedlings were exposed to $0,0.5$, or $1 \mu \mathrm{M}$ Indole Acetic Acid (IAA) while in liquid culture (0.2 g/L NPK 20-20-20). Solutions containing $0 \mu \mathrm{M}$ IAA were inoculated with a mock dose containing DMSO, which was used as a hormone solvent. Root and shoot growth were measured prior to and following seven days of auxin exposure. The difference in growth during the treatment period $=$ Trait $X$ post-treatment minus Trait $X$ pre-treatment. In a separate experiment, wildtype and osarf1 $1^{\text {TRIM }}$ seeds were germinated on half-strength MS supplemented with $0,12.5$, and $25 \mu \mathrm{M}$ phenylboronic acid (PBA, BB-2375, Combi-Blocks, Inc., San Diego, CA, USA) to determine the effect of PBA on longitudinal vein development in the second, third, and fourth leaves of the primary shoot.

For root gravitropism responses, seeds from both genotypes were first plated on half strength MS and grown vertically for six days. Plates were thereafter rotated at a 90-degree angle and evaluated after $24 \mathrm{~h}$. Root curvature was measured using ImageJ software [78] as described [63].

\subsection{Microscopy}

Seedlings were fixed overnight in a 6:1 solution of ethanol to acetic acid, followed by a brief wash in $50 \%$ ethanol. Individual leaves were collected and cleared in lactic acid by heating to $95^{\circ} \mathrm{C}$ for $30 \mathrm{~min}$. Explants were mounted in a 30\% aqueous glycerol solution. Leaf venation was observed using differential interference contrast in a Nikon Eclipse E600 microscope (EquipNet, Inc. Canton, MA, USA). Images were captured with a Canon EOS 5D Mark II camera (Henry's Camera, Vancouver, BC, Canada). 


\subsection{Statistical Analysis}

Statistical analyses were conducted in JMP (SAS, Cary, NC, USA) using a one-way analysis of variance (ANOVA) test and Student's $t$ test. Associated graphs were generated in Excel. As osarf11 mutant phenotypes were not fully penetrant, measurements from repeat trials were combined into a single data set to increase sample size. Two or more growth trials were conducted per experiment.

\section{Conclusions}

The OsARF11 gene has appeared in gene expression studies and its protein as an interactor with other proteins with key roles in rice development, but a thorough analysis of its function based on mutant analysis has to-date been lacking. This study fills that gap in knowledge and provides evidence that OSARF11 acts in auxin-dependent processes throughout the rice life cycle. OsARF11 promotes both root and leaf growth, formation of roots, panicle branches, grains, and higher-order veins. We also found evidence for a role in auxin perception, response to gravitropic stimulus, as well as seed formation and development. While osarf11 seedlings did not display the patterning defects seen in mutants of its potential $A$. thaliana ortholog MP/ARF5, we saw a partial overlap in vein and reproductive lateral organ formation, suggesting that OsARF11 may have functions similar to MP/ARF5 in some processes. This study provides the baseline needed for more detailed studies on the role of OSARF11 in these developmental processes and suggests a role of OsARF11 in key quantitative traits in this economically important species.

Supplementary Materials: The following are available online at https:/ /www.mdpi.com/article/10 .3390/ijms22084089/s1, Figure S1: Identification of homozygous Osarf11 ${ }^{T O S 17}$ mutants. Figure S2: Sequence of TRIM T-DNA $3^{\prime}$ end insertion point. Figure S3: Insertion of TOS17 transposon in the OsARF11 gene. Figure S4: Height phenotype of two-month-old osarf11 mutants. Figure S5: Tertiary vein initiation in osarf11 ${ }^{\text {TRIM }}$ relative to wildtype. Table S1: Quantitative phenotypes measured in osarf11 $1^{\text {TRIM }}$ plants. Table S2: Leaf venation defects in osarf11 ${ }^{\text {TRIM }}$ seedlings., Table S3: Quantitative phenotypes observed in osarf11 ${ }^{\text {TOS-17 }}$ plants.

Author Contributions: Conceptualization, J.M.; methodology, K.S., F.A.-S., N.S., M.G.M.H.; formal analysis, K.S., F.A.-S., N.S., M.G.M.H. investigation, K.S., F.A.-S., N.S., M.G.M.H.; data curation, K.S., F.A.-S., N.S., M.G.M.H.; writing-original draft preparation, K.S. and J.M.; writing-review and editing, K.S., J.M., M.G.M.H.; visualization, K.S.; supervision, J.M.; project administration, J.M.; funding acquisition, J.M. All authors have read and agreed to the published version of the manuscript.

Funding: This research was funded by the Natural Sciences and Engineering Research Council (NSERC) discovery grant to J.M., MITACS Accelerate Fellowship to K.S., and MITACS Globalink fellowship to M.G.M.H.

Acknowledgments: We are grateful for the mutant seeds provided by the Taiwan Rice Insertional Mutant (TRIM) seed bank, and the Genetic Resources Center, National Agriculture and Food Research Organization, Japan. We thank Lily Teng and Su-May Yu (Institute of Molecular Biology, Academia Sinica, Taiwan) for initial genotyping of TRIM mutants. We thank reviewers for constructive comments on the manuscript.

Conflicts of Interest: The authors declare no conflict of interest. The funders had no role in the design of the study; in the collection, analyses, or interpretation of data; in the writing of the manuscript, or in the decision to publish the results.

\section{References}

1. Kajala, K.; Covshoff, S.; Karki, S.; Woodfield, H.; Tolley, B.J.; Dionora, M.J.A.; Mogul, R.T.; Mabilangan, A.E.; Danila, F.R.; Hibberd, J.M.; et al. Strategies for engineering a two-celled C 4 photosynthetic pathway into rice. J. Exp. Bot. 2011, 62, 3001-3010. [CrossRef]

2. Wang, P.; Vlad, D.; Langdale, J.A. Finding the genes to build C4 rice. Curr. Opin. Plant Biol. 2016, 31, 44-50. [CrossRef]

3. Perrot-Rechenmann, C. Cellular responses to auxin: Division versus expansion. Cold Spring Harb. Perspect. Biol. 2010,2 , a001446. [CrossRef] [PubMed]

4. Scarpella, E.; Helariutta, Y. Vascular Pattern Formation in Plants. Curr. Top. Dev. Biol. 2010, 91, 221-265. [PubMed] 
5. Aloni, R. The Induction of Vascular Tissues by Auxin. In Plant Hormones; Springer: Dordrecht, The Netherlands, 2010; pp. 485-518.

6. Smit, M.E.; Weijers, D. The role of auxin signaling in early embryo pattern formation. Curr. Opin. Plant Biol. 2015, 28, 99-105. [CrossRef] [PubMed]

7. Reinhardt, D.; Pesce, E.R.; Stieger, P.; Mandel, T.; Baltensperger, K.; Bennett, M.; Traas, J.; Friml, J.; Kuhlemeier, C. Regulation of phyllotaxis by polar auxin transport. Nature 2003, 426, 255-260. [CrossRef] [PubMed]

8. Scarpella, E.; Marcos, D.; Friml, J.; Berleth, T. Control of leaf vascular patterning by polar auxin transport. Genes Dev. 2006, 20, 1015-1027. [CrossRef]

9. Weijers, D.; Wagner, D. Transcriptional Responses to the Auxin Hormone. Annu. Rev. Plant Biol. 2016, 67, 539-574. [CrossRef]

10. Chandler, J.W. Auxin response factors. Plant Cell Environ. 2016, 39, 1014-1028. [CrossRef] [PubMed]

11. Vernoux, T.; Brunoud, G.; Farcot, E.; Morin, V.; Van Den Daele, H.; Legrand, J.; Oliva, M.; Das, P.; Larrieu, A.; Wells, D.; et al. The auxin signalling network translates dynamic input into robust patterning at the shoot apex. Mol. Syst. Biol. 2011, 7, 508. [CrossRef]

12. Calderón Villalobos, L.I.A.; Lee, S.; De Oliveira, C.; Ivetac, A.; Brandt, W.; Armitage, L.; Sheard, L.B.; Tan, X.; Parry, G.; Mao, H.; et al. A combinatorial TIR1/AFB-Aux/IAA co-receptor system for differential sensing of auxin. Nat. Chem. Biol. 2012, 8, 477-485. [CrossRef]

13. Powers, S.K.; Strader, L.C. Regulation of auxin transcriptional responses. Dev. Dyn. 2020, 249, 483-495. [CrossRef]

14. Kepinski, S.; Leyser, O. The Arabidopsis F-box protein TIR1 is an auxin receptor. Nature 2005, 435, 446-451. [CrossRef]

15. Sharon, M.; Zheng, C.; Zheng, N.; Calderon-Villalobos, L.I.A.; Estelle, M.; Tan, X.; Robinson, C.V. Mechanism of auxin perception by the TIR1 ubiquitin ligase. Nature 2007, 446, 640-645.

16. Ulmasov, T. ARF1, a Transcription Factor That Binds to Auxin Response Elements. Science 1997, 276, 1865-1868. [CrossRef]

17. Freire-Rios, A.; Tanaka, K.; Crespo, I.; Van der Wijk, E.; Sizentsova, Y.; Levitsky, V.; Lindhoud, S.; Fontana, M.; Hohlbein, J.; Roeland Boer, D.; et al. Architecture of DNA elements mediating ARF transcription factor binding and auxin-responsive gene expression in Arabidopsis. Proc. Natl. Acad. Sci. USA 2020, 117, 24557-24566. [CrossRef]

18. Pierre-Jerome, E.; Moss, B.L.; Lanctot, A.; Hageman, A.; Nemhauser, J.L. Functional analysis of molecular interactions in synthetic auxin response circuits. Proc. Natl. Acad. Sci. USA 2016, 113, 11354-11359. [CrossRef]

19. Stigliani, A.; Martin-Arevalillo, R.; Lucas, J.; Bessy, A.; Vinos-Poyo, T.; Mironova, V.; Vernoux, T.; Dumas, R.; Parcy, F. Capturing auxin response factors syntax using DNA binding models. Mol. Plant 2019, 12, 822-832. [CrossRef]

20. Wu, M.F.; Yamaguchi, N.; Xiao, J.; Bargmann, B.; Estelle, M.; Sang, Y.; Wagner, D. Auxin-regulated chromatin switch directs acquisition of flower primordium founder fate. Elife 2015, 4, e09269. [CrossRef] [PubMed]

21. Roosjen, M.; Paque, S.; Weijers, D. Auxin Response Factors: Output control in auxin biology. J. Exp. Bot. 2018, 69, 179-188. [CrossRef]

22. Przemeck, G.K.H.; Mattsson, J.; Hardtke, C.S.C.S.; Sung, Z.R.R.; Berleth, T. Studies on the role of the Arabidopsis gene MONOPTEROS in vascular development and plant cell axialization. Planta 1996, 200, 229-237. [CrossRef] [PubMed]

23. Berleth, T.; Jurgens, G. The role of the monopteros gene in organising the basal body region of the Arabidopsis embryos. Trends Genet. 2008, 9, 299.

24. Hardtke, C.S.; Ckurshumova, W.; Vidaurre, D.P.; Singh, S.A.; Stamatiou, G.; Tiwari, S.B.; Hagen, G.; Guilfoyle, T.J.; Berleth, T. Overlapping and non-redundant functions of the Arabidopsis auxin response factors MONOPTEROS and NONPHOTOTROPIC HYPOCOTYL 4. Development 2004, 131, 1089-1100. [CrossRef]

25. Hardtke, C.S.; Berleth, T. The Arabidopsis gene MONOPTEROS encodes a transription factor mediating embryo axis formation and vascular development. EMBO J. 1998, 17, 1405-1411. [CrossRef] [PubMed]

26. Wenzel, C.L.; Schuetz, M.; Yu, Q.; Mattsson, J. Dynamics of MONOPTEROS and PIN-FORMED1 expression during leaf vein pattern formation in Arabidopsis thaliana. Plant J. 2007, 49, 387-398. [CrossRef] [PubMed]

27. Schuetz, M.; Berleth, T.; Mattsson, J. Multiple MONOPTEROS-dependent pathways are involved in leaf initiation. Plant Physiol. 2008, 148, 870-880. [CrossRef] [PubMed]

28. Schlereth, A.; Möller, B.; Liu, W.; Kientz, M.; Flipse, J.; Rademacher, E.H.; Schmid, M.; Jürgens, G.; Weijers, D. MONOPTEROS controls embryonic root initiation by regulating a mobile transcription factor. Nature 2010, 464, 913-916. [CrossRef]

29. Bhatia, N.; Bozorg, B.; Larsson, A.; Ohno, C.; Jönsson, H.; Heisler, M.G. Auxin Acts through MONOPTEROS to Regulate Plant Cell Polarity and Pattern Phyllotaxis. Curr. Biol. 2016, 26, 3202-3208. [CrossRef]

30. Nemhauser, J.L.; Feldman, L.J.; Zambryski, P.C. Auxin and ETTIN in Arabidopsis gynoecium morphogenesis. Development 2000, 127, 3877-3888.

31. Simonini, S.; Deb, J.; Moubayidin, L.; Stephenson, P.; Valluru, M.; Freire-Rios, A.; Sorefan, K.; Weijers, D.; Friml, J.; Østergaard, L. A noncanonical auxin-sensing mechanism is required for organ morphogenesis in arabidopsis. Genes Dev. 2016, 30, 2286-2296. [CrossRef]

32. Ellis, C.M.; Nagpal, P.; Young, J.C.; Hagen, G.; Guilfoyle, T.J.; Reed, J.W. AUXIN RESPONSE FACTOR1 and AUXIN RESPONSE FACTOR2 regulate senescence and floral organ abscission in Arabidopsisthaliana. Development 2005, 132, 4563-4574. [CrossRef]

33. Shin, R.; Burch, A.Y.; Huppert, K.A.; Tiwari, S.B.; Murphy, A.S.; Guilfoyle, T.J.; Schachtman, D.P. The Arabidopsis Transcription Factor MYB77 Modulates Auxin Signal Transduction. Plant Cell Online 2007, 19, 2440-2453. [CrossRef]

34. Salehin, M.; Li, B.; Tang, M.; Katz, E.; Song, L.; Ecker, J.R.; Kliebenstein, D.J.; Estelle, M. Auxin-sensitive Aux/IAA proteins mediate drought tolerance in Arabidopsis by regulating glucosinolate levels. Nat. Commun. 2019, 10, 1-9. [CrossRef] 
35. Perez-Torres, C.-A.; Lopez-Bucio, J.; Cruz-Ramirez, A.; Ibarra-Laclette, E.; Dharmasiri, S.; Estelle, M.; Herrera-Estrella, L. Phosphate Availability Alters Lateral Root Development in Arabidopsis by Modulating Auxin Sensitivity via a Mechanism Involving the TIR1 Auxin Receptor. Plant Cell 2008, 20, 3258-3272. [CrossRef]

36. Sato, Y.; Nishimura, A.; Ito, M.; Ashikari, M.; Hirano, H.-Y.; Matsuoka, M. Auxin response factor family in rice. Genes Genet. Syst. 2001, 76, 373-380. [CrossRef]

37. Wang, D.; Pei, K.; Fu, Y.; Sun, Z.; Li, S.; Liu, H.; Tang, K.; Han, B.; Tao, Y. Genome-wide analysis of the auxin response factors (ARF) gene family in rice (Oryza sativa). Gene 2007, 394, 13-24. [CrossRef]

38. Attia, K.A.; Abdelkhalik, A.F.; Ammar, M.H.; Wei, C.; Yang, J.; Lightfoot, D.A.; El-Sayed, W.M.; El-Shemy, H.A. Antisense phenotypes reveal a functional expression of OsARF1, an auxin response factor, in transgenic rice. Curr. Issues Mol. Biol. 2009, $11,11$.

39. Shen, C.; Yue, R.; Sun, T.; Zhang, L.; Yang, Y.; Wang, H. OsARF16, a transcription factor regulating auxin redistribution, is required for iron deficiency response in rice (Oryza sativa L.). Plant Sci. 2015, 231, 148-158. [CrossRef]

40. Shen, C.; Yue, R.; Yang, Y.; Zhang, L.; Sun, T.; Tie, S.; Wang, H. OsARF16 is involved in cytokinin-mediated inhibition of phosphate transport and phosphate signaling in rice (Oryza sativa L.). PLoS ONE 2014, 9, e112906. [CrossRef]

41. Wang, S.; Zhang, S.; Sun, C.; Xu, Y.; Chen, Y.; Yu, C.; Qian, Q.; Jiang, D.A.; Qi, Y. Auxin response factor (OsARF12), a novel regulator for phosphate homeostasis in rice (Oryza sativa). New Phytol. 2014, 201, 91-103. [CrossRef]

42. Qi, Y.; Wang, S.; Shen, C.; Zhang, S.; Chen, Y.; Xu, Y.; Liu, Y.; Wu, Y.; Jiang, D. OsARF12, a transcription activator on auxin response gene, regulates root elongation and affects iron accumulation in rice (Oryza sativa). New Phytol. 2012, 193, 109-120. [CrossRef]

43. Huang, J.; Li, Z.; Zhao, D. Deregulation of the OsmiR160 target gene OsARF18 causes growth and developmental defects with an alteration of auxin signaling in rice. Sci. Rep. 2016, 6, 1-14. [CrossRef] [PubMed]

44. Sakamoto, T.; Inukai, Y. Characterization of a Tos17 Insertion Mutant of Rice Auxin Signal Transcription Factor Gene, OsARF24. Am. J. Plant Sci. 2013, 4, 84-91. [CrossRef]

45. Zhang, S.; Wu, T.; Liu, S.; Liu, X.; Jiang, L.; Wan, J. Disruption of OsARF19 is Critical for Floral Organ Development and Plant Architecture in Rice (Oryza sativa L.). Plant Mol. Biol. Report. 2016, 34, 748-760. [CrossRef]

46. Zhang, S.; Wang, S.; Xu, Y.; Yu, C.; Shen, C.; Qian, Q.; Geisler, M.; Jiang, D.A.; Qi, Y. The auxin response factor, OsARF19, controls rice leaf angles through positively regulating OsGH3-5 and OsBRI1. Plant Cell Environ. 2015, 38, 638-654. [CrossRef] [PubMed]

47. Chen, S.H.; Zhou, L.J.; Xu, P.; Xue, H.W. SPOC domain-containing protein Leaf inclination3 interacts with LIP1 to regulate rice leaf inclination through auxin signaling. PLoS Genet. 2018, 14, e1007829. [CrossRef]

48. Li, Y.; Li, J.; Chen, Z.; Wei, Y.; Qi, Y.; Wu, C. OsmiR167a-targeted auxin response factors modulate tiller angle via fine-tuning auxin distribution in rice. Plant Biotechnol. J. 2020, 18, 2015-2026. [CrossRef]

49. Hsing, Y.I.; Chern, C.G.; Fan, M.J.; Lu, P.C.; Chen, K.T.; Lo, S.F.; Sun, P.K.; Ho, S.L.; Lee, K.W.; Wang, Y.C.; et al. A rice gene activation/knockout mutant resource for high throughput functional genomics. Plant Mol. Biol. 2007, 63, 351-364. [CrossRef]

50. Hirochika, H. Contribution of the Tos17 retrotransposon to rice functional genomics. Curr. Opin. Plant Biol. 2001, 4, 118-122. [CrossRef]

51. Song, Y.; Wang, L.; Xiong, L. Comprehensive expression profiling analysis of OsIAA gene family in developmental processes and in response to phytohormone and stress treatments. Planta 2009, 229, 577-591. [CrossRef]

52. Waese, J.; Fan, J.; Pasha, A.; Yu, H.; Fucile, G.; Shi, R.; Cumming, M.; Kelley, L.A.; Sternberg, M.J.; Krishnakumar, V.; et al. ePlant: Visualizing and exploring multiple levels of data for hypothesis generation in plant biology. Plant Cell 2017, 29, 1806-1821. [CrossRef] [PubMed]

53. Liu, X.; Yang, C.Y.; Miao, R.; Zhou, C.L.; Cao, P.H.; Lan, J.; Zhu, X.J.; Mou, C.L.; Huang, Y.S.; Liu, S.J.; et al. DS1/OsEMF1 interacts with OsARF11 to control rice architecture by regulation of brassinosteroid signaling. Rice 2018, 11, 46. [CrossRef] [PubMed]

54. Sakamoto, T.; Morinaka, Y.; Inukai, Y.; Kitano, H.; Fujioka, S. Auxin signal transcription factor regulates expression of the brassinosteroid receptor gene in rice. Plant J. 2013, 73, 676-688. [CrossRef] [PubMed]

55. Qi, J.; Qian, Q.; Bu, Q.; Li, S.; Chen, Q.; Sun, J.; Liang, W.; Zhou, Y.; Chu, C.; Li, X.; et al. Mutation of the rice narrow leaf1 gene, which encodes a novel protein, affects vein patterning and polar auxin transport. Plant Physiol. 2008, 147, 1947-1959. [CrossRef] [PubMed]

56. Matthes, M.; Torres-Ruiz, R.A. Boronic acid treatment phenocopies monopteros by affecting PIN1 membrane stability and polar auxin transport in Arabidopsis thaliana embryos. Development 2016, 143, 4053-4062. [CrossRef] [PubMed]

57. Band, L.R.; Wells, D.M.; Larrieu, A.; Sun, J.; Middleton, A.M.; French, A.P.; Brunoud, G.; Sato, E.M.; Wilson, M.H.; Peŕet, B.; et al. Root gravitropism is regulated by a transient lateral auxin gradient controlled by a tipping-point mechanism. Proc. Natl. Acad. Sci. USA 2012, 109, 4668-4673. [CrossRef]

58. Ottenschläger, I.; Wolff, P.; Wolverton, C.; Bhalerao, R.P.; Sandberg, G.; Ishikawa, H.; Evans, M.; Palme, K. Gravity-regulated differential auxin transport from columella to lateral root cap cells. Proc. Natl. Acad. Sci. USA 2003, 100, 2987-2991. [CrossRef] [PubMed]

59. Fujino, K.; Matsuda, Y.; Ozawa, K.; Nishimura, T.; Koshiba, T.; Fraaije, M.W.; Sekiguchi, H. NARROW LEAF 7 controls leaf shape mediated by auxin in rice. Mol. Genet. Genom. 2008, 279, 499-507. [CrossRef]

60. Xu, Y.; Hu, D.; Hou, X.; Shen, J.; Liu, J.; Cen, X.; Fu, J.; Li, X.; Hu, H.; Xiong, L. OsTMF attenuates cold tolerance by affecting cell wall properties in rice. New Phytol. 2020, 227, 498-512. [CrossRef] [PubMed] 
61. Du, M.; Spalding, E.P.; Gray, W.M. Rapid Auxin-Mediated Cell Expansion. Annu. Rev. Plant Biol. 2020, 71, 379-402. [CrossRef]

62. Wang, R.; Zhang, Y.; Kieffer, M.; Yu, H.; Kepinski, S.; Estelle, M. HSP90 regulates temperature-dependent seedling growth in Arabidopsis by stabilizing the auxin co-receptor F-box protein TIR1. Nat. Commun. 2016, 7, 10269. [CrossRef]

63. Inukai, Y.; Sakamoto, T.; Ueguchi-Tanaka, M.; Shibata, Y.; Gomi, K.; Umemura, I.; Hasegawa, Y.; Ashikari, M.; Kitano, H.; Matsuoka, M. Crown rootless1, which is essential for crown root formation in rice, is a target of an Auxin Response Factor in auxin signaling. Plant Cell 2005, 17, 1387-1396. [CrossRef]

64. Mariyamma, N.P.; Hou, H.; Carland, F.M.; Nelson, T.; Schultz, E.A. Localization of Arabidopsis FORKED1 to a RABA-positive compartment suggests a role in secretion. J. Exp. Bot. 2017, 68, 3375-3390. [CrossRef]

65. Prabhakaran Mariyamma, N.; Clarke, K.J.; Yu, H.; Wilton, E.E.; Van Dyk, J.; Hou, H.; Schultz, E.A. Members of the Arabidopsis FORKED1-LIKE gene family act to localize PIN1 in developing veins. J. Exp. Bot. 2018, 69, 4773-4790. [CrossRef]

66. Sieburth, L.E.; Muday, G.K.; King, E.J.; Benton, G.; Kim, S.; Metcalf, K.E.; Meyers, L.; Seamen, E.; Van Norman, J.M. SCARFACE encodes an ARF-GAP that is required for normal auxin efflux and vein patterning in Arabidopsis. Plant Cell 2006, 18, 1396-1411. [CrossRef]

67. Baylis, T.; Cierlik, I.; Sundberg, E.; Mattsson, J. SHORT INTERNODES/STYLISH genes, regulators of auxin biosynthesis, are involved in leaf vein development in Arabidopsis thaliana. New Phytol. 2013, 197, 737-750. [CrossRef]

68. Nelson, T.; Dengler, N. Leaf vascular pattern formation. Plant Cell 1997, 9, 1121-1135. [CrossRef]

69. Pantin, F.; Simonneau, T.; Muller, B. Coming of leaf age: Control of growth by hydraulics and metabolics during leaf ontogeny. New Phytol. 2012, 196, 349-366. [CrossRef]

70. Feldman, A.B.; Leung, H.; Baraoidan, M.; Elmido-Mabilangan, A.; Canicosa, I.; Quick, W.P.; Sheehy, J.; Murchie, E.H. Increasing leaf vein density via mutagenesis in rice results in an enhanced rate of photosynthesis, smaller cell sizes and can reduce interveinal mesophyll cell number. Front. Plant Sci. 2017, 8, 1883. [CrossRef]

71. Nardini, A.; Ounapuu-Pikas, E.; Savi, T. When smaller is better: Leaf hydraulic conductance and drought vulnerability correlate to leaf size and venation density across four Coffea arabica genotypes. Funct. Plant Biol. 2014, 41, 972-982. [CrossRef]

72. Scoffoni, C.; Chatelet, D.S.; Pasquet-Kok, J.; Rawls, M.; Donoghue, M.J.; Edwards, E.J.; Sack, L. Hydraulic basis for the evolution of photosynthetic productivity. Nat. Plants 2016, 2, 1-8. [CrossRef]

73. Mattsson, J.; Ckurshumova, W.; Berleth, T. Auxin Signaling in Arabidopsis Leaf Vascular Development. Plant Physiol. 2003, 131, 1327-1339. [CrossRef]

74. Wenzel, C.L.; Hester, Q.; Mattsson, J. Identification of genes expressed in vascular tissues using NPA-induced vascular overgrowth in Arabidopsis. Plant Cell Physiol. 2008, 49, 457-468. [CrossRef] [PubMed]

75. Geldner, N.; Anders, N.; Wolters, H.; Keicher, J.; Kornberger, W.; Muller, P.; Delbarre, A.; Ueda, T.; Nakano, A.; Jürgens, G. The Arabidopsis GNOM ARF-GEF mediates endosomal recycling, auxin transport, and auxin-dependent plant growth. Cell 2003, 112, 219-230. [CrossRef]

76. Mayer, U.; Ruiz, R.A.T.; Berleth, T.; Miseéra, S.; Jürgens, G. Mutations affecting body organization in the Arabidopsis embryo. Nature 1991, 353, 402-407. [CrossRef]

77. Sakai, H.; Lee, S.S.; Tanaka, T.; Numa, H.; Kim, J.; Kawahara, Y.; Wakimoto, H.; Yang, C.C.; Iwamoto, M.; Abe, T.; et al. Rice annotation project database (RAP-DB): An integrative and interactive database for rice genomics. Plant Cell Physiol. 2013, 54, e6. [CrossRef]

78. Schneider, C.A.; Rasband, W.S.; Eliceiri, K.W. NIH Image to ImageJ: 25 years of image analysis. Nat. Methods 2012, 9, 671-675. [CrossRef] 